\title{
A literatura frenética finissecular nos folhetins de Gomes Leal
}

\author{
Maria Cristina Batalha ${ }^{1}$
}

\begin{abstract}
Resumo: A produção novelística de António Duarte Gomes Leal (1848-1921), um dos mais novos da Geração de 70, é marcada por uma tensão erótica, entre o delírio e o mistério, nos moldes da chamada "literatura frenética", dominante, na França, nos meados do século XIX, e mais para o fim do século, em Portugal, coincidindo com o período conhecido por "decadentismo". Em sua obra, Eros é submetido à dor e à morte, e as paixões violentas se desenvolvem em locais soturnos, imersos em escuridão, nos quais predomina o sentimento de aprisionamento face ao exterior (cemitérios, castelos). O satanismo manifesta-se no gosto pelo excesso e o arrebatamento. Através de três novelas de Gomes Leal, publicadas em fascículos como brinde aos leitores do jornal Diário de Notícias, destacam-se a concepsão de um universo marcado pelo fantástico e o grotesco, pelo masoquismo e o sadismo, expressando uma visão dualista do homem, inspirada em Baudelaire, e bem ao gosto dos leitores dos folhetins do final do século XIX.
\end{abstract}

Palavras-chave: Gomes Leal. Literatura frenética. Folhetim. Decadentismo.

Por volta da segunda metade do século XIX, surge em Portugal um gosto acentuado do público leitor pelo gótico e o frenético que lhe chegavam sobretudo através dos folhetins franceses. Sustentada por imagens hiperbólicas, uma retórica da crueldade e das paixões mórbidas, a literatura frenética trazia à cena os excessos do mundo real, fazendo eco ao jornalismo sensacionalista que noticiava crimes e castigos, visando atingir o grande público, ávido por esse tipo de leitura e toda carga de emoção que ela suscitava. Trata-se da chamada literatura romântica frenética, nome atribuído pelo escritor francês Charles Nodier, em um artigo de Annales de la Littérature et des Arts (1821), para referir-se à poética do exagero retórico, identificado com um certo mau-gosto devido ao uso exacerbado de figuras de estilo, e que tinha como objetivo provocar efeitos emocionais fortes no leitor.

Em sua configuração, o frenesi romântico carrega traços do romance gótico inglês (roman noir), do fantástico alemão e do erotismo violento e escatológico, característico da estética desenvolvida pelo marquês de Sade, considerado o ilustre e maldito precursor da expressão literária do frenesi. Esse modo de representação oscila entre o excesso e o não-

\footnotetext{
${ }^{1}$ Doutora em Literatura Comparada pela UFF (2003). Professora Associada do Instituto de Letras da UERJ. Desenvolve o projeto "Literatura menor, literatura maior (II)" na UERJ. Agências de fomento: CNPq; UERJ; FAPERJ, Brasil. Rio de Janeiro. E-mail: cbatalh@gmail.com Orcid: http://orcid.org./0000-0002-4957-0560
} 
dito, a exibição e o encobrimento, o desvelar e o subentendido. Tal retórica estimula um pathos de exaltação que buscava levar o leitor ao êxtase através de emoções fortes, muitas vezes proporcionadas pelo horror de inspiração gótica. Esse viés literário domina a cena europeia e passa a servir de modelo de emulação para diversas literaturas de países como Portugal, Espanha e Brasil, que seguiam de perto os modismos da França e da Inglaterra.

Por outro lado, paralelamente a essa literatura considerada "menor", veiculada sobretudo pelos jornais da época, impunha-se na cena literária uma nova poética, de viés simbolista, identificada com o sentimento dominante de decadência tanto do ponto de vista pessoal do artista em sua prática, quanto do ponto de vista da sociedade em geral, e em particular a portuguesa, que vivia seus abalos políticos e sociais. Predomina, então, no cenário artístico europeu, a vocação para uma literatura de índole satânica, nos moldes trilhados pela poesia do Mal e do ceticismo, tendência quase que generalizada da geração de 1865. Desenhava-se, assim, um cenário de erotismo e terror , compondo o quadro amoroso do "decadentismo" : luxo, desejo, sangue, morte, fatalismo macabro e volúpia. Como expressão dominante e figura quase central dessa nova poética, destaca-se um fenômeno estético novo, encarnado por uma figura mítica, mulher monstro de beleza e de violência, decantada à exaustão pelo romantismo, antes de encontrar novos avatares decadentes. $\mathrm{O}$ mito romântico de Dom Juan, criado por Tarso de Molina, é também revertido, pois há a transferência da capacidade de sedução para o sexo feminino, além de denunciar o afastamento da concepção romântica do amor como idealismo e a apologia do instinto sexual como gênese das relações amorosas.

O fim do século em Portugal é uma época marcada por transformações políticas e sociais que geraram insegurança e levaram ao sentimento de decadência de usos e costumes, suscitando a nostalgia do que era - e que não cabia mais -, e, ao mesmo tempo, a incerteza sobre o novo cujo desenho era ainda fluido. Assim, vinham-se conjugar a sedução da novidade e a angústia sobre sua natureza ainda incerta. Além disso, no campo das artes, esse era também um momento de transição na cena literária, marcada pela passagem do romantismo ao realismo.

A literatura finissecular, que trazia à tona o bas-fond da sociedade, fazia o elo entre o gótico e o Naturalismo e, ao mesmo tempo, alimentava os folhetins da época, respondendo a um certo gosto do público. Com efeito, o frenesi da literatura folhetinesca, em sintonia 


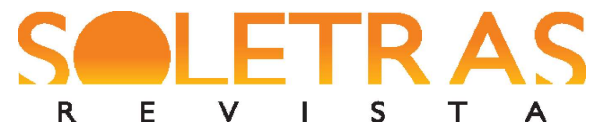

N. $40-2020.2$ - MARIA CRISTINA BATALHA

com as angústias e pretensões estéticas dos romancistas e, sobretudo, dos poetas finesseculares, exacerba-se em produções que apelam para cenas de crueldade e cenários melodramáticos ou fantásticos. Essas narrativas, além de incrementar a venda de jornais e permitir que escritores pudessem viver de sua pena, promoveram a catarse entre seus leitores, ajudando-os a lidar com seus próprios desejos, emoções, incertezas e temores. Como destaca Andréa Castro:

No processo de ordenamento da sociedade burguesa, destaca-se a presença do "crime", amplamente divulgado pela imprensa da época e fazendo o deleite de inúmeros leitores que corriam aos jornais para inteirar-se dos acontecimentos. Os casos escabrosos exerciam um verdadeiro fascínio junto ao público leitor, justificando o sucesso angariado pela série de "Mistérios" publicados à época, tanto na França como em Portugal. (CASTRO, 2017, p. 39. Os destaques são da autora.)

E a leitura desses escritos povoados de crime, violência e horror serve como válvula de escape para as agruras do cotidiano opressivo, distendendo as tensões acumuladas, conforme assinala Christine Marcandier-Colard:

O crime é a matéria e o fermento da literatura romântica, a fonte de um novo prazer literário, o instrumento de uma verdadeira topografia imaginária: com efeito, o teatro de sangue dá sistematicamente lugar à definição de um espaço, funcionando como um texto. O lugar deve assim ser compreendido em seu sentido mais literário: lugar do corpo (encruzilhada da beleza e da violência, espaço de preparação e de instalação do crime que vai acontecer), lugar como cenário (arenas, teatros, local da guilhotina, mas também alcovas, como em La fille aux yeux d'or [Balzac]). ${ }^{2}$ (MARCANDIER-COLARD, 1998, p. 9)

\footnotetext{
${ }^{2}$ Le crime est le matériau et le levain de la littérature romantique, la source d'un nouveau plaisir littéraire, l'instrument d'une véritable topographie imaginaire: en effe le théâtre du sang donne systématiquement lieu à la définition d'un espace, fonctionnant comme un texte. Le lieu doit ainsi être compris dans son sens le plus littéraire:lieux du corps (carrefour de la beauté et de la violence, espace de préparation et de mise en place de la scène du meurtre à venir), lieux du décor (arènes, théâtres, places de la guillotine mais aussi boudoirs, comme celui de La fille aux yeux d'or). As traduções dos originais em língua estrangeira são de minha responsabilidade.
} 


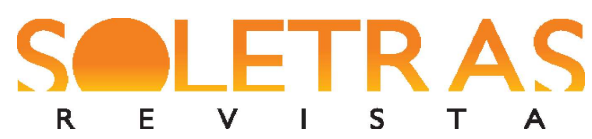

N. $40-2020.2$ - MARIA CRISTINA BATALHA

É nesse quadro de referência que trazemos o escritor, jornalista e poeta António Duarte Gomes Leal (1848-1921), um dos mais novos da Geração de 70. Como destacam alguns críticos, este estabelece um elo entre essa geração e a poesia que se segue, identificada como simbolista-decadente. Com efeito, as primeiras publicações de Gomes Leal surgem em meio à polêmica coimbrã, desencadeada pela publicação, em 1862, do livro de poemas D. Jaime, de Tomás Ribeiro, com Prefácio de Castilho, afigurando-se como uma demonstração cabal da morte da "poesia romântica portuguesa" (MACHADO, 1992, p. 110). Por esta época, Portugal era um país onde abundavam ainda resquícios de romantismo, um país em que a modernização tardia da Regeneração se fazia sentir já sob o peso ameaçador de uma dívida externa incontornável. Os meandros da política denunciavam os vícios de um rotativismo partidário que o sistema constitucionalista originara. Vinte anos depois, parte desse grupo de jovens idealistas da Geração de 70 assumia-se como os "Vencidos da Vida". (FRANCISCO, in LOURENÇO, SANTANA \& SIMÕES, 2013, p. 129).

Em ensaio sobre Gomes Leal, Álvaro Manuel Machado aponta o diálogo do autor com a tradição romântica portuguesa, notadamente Garrett e Herculano, e também "um sentido finissecular baudelairiano", definido como um "certo culto do vazio social e religioso" que impera no final do século XIX (MACHADO, 1992, p. 110). Esse "vazio" não era uma particularidade de Portugal e estava sendo vivenciado por toda uma geração de escritores na Europa. Apesar do processo acelerado de desenvolvimento econômico, em carta enviada ao jovem amigo J.-K. Huysmans, em abril de 1891, Jean Lorrain descreve a atmosfera intelectual do período, que se expressava na ficção de um modo novo e bastante peculiar: "No fundo, como somos atormentados, meu pobre amigo, e quão miseráveis por termos vindo tão tarde na fraqueza desses tempos". E, ao final da mesma carta, declara que seu consolo seria conseguir, com a sua obra, "abalar um pouco alguns nervosos e alguns obcecados como você e eu (LORRAIN, apud. SILVA, 2019, p. 9).

Ciente da novidade que pautava a produção poética finissecular, em 1881, Gomes Leal proclama n'O Século que era “a primeira vez que nós introduzimos a poesia panteísta em Portugal, assim como Teófilo Braga introduzira a poesia histórica, e Antero de Quental a poesia social", pois "um grande clamor se levantou então à roda dos folhetins que publicávamos na Revolução de Setembro". Chamavam "satanismo" a essa poesia e diziam-na derivada de Byron e de Musset” (LEAL in NEMÉSIO, 1953, p. 15). Assim, à ideia de decadência nacional e 


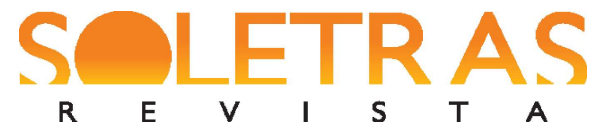

N. 40 - 2020.2 - MARIA CRISTINA BATALHA

pessimismo histórico, somava-se, no terreno das artes, o desejo de romper com os parâmetros poéticos da geração romântico-realista. A título de ilustração, destacamos as declarações de Antero de Quental, proferidas por ocasião das comemorações do tricentenário de Camões: "há nações para as quais a Epopeia é ao mesmo tempo o epitáfio", e, como adverte o crítico, "palavras que corroboram o final d'O crime do Padre Amaro, de Eça de Queirós: 'pátria para sempre passada, memória quase perdida"'(in NEMÉSIO, 1953, p. 16).

Embora Gomes Leal seja conhecido sobretudo por sua poesia, notadamente a partir de Claridades do Sul (1875), a ambiência decadentista e sua retórica particular perpassam toda a sua obra e, como observa Cecília Barreira:

Toda a literatura decadente, na qual se insere parte da produção poética do autor, elege como espaços privilegiados os locais soturnos, imersos em escuridão ou em parca luminosidade. Normalmente designam espaços concêntricos isolados, auto-regulando-se por um aprisionamento face ao exterior (cemitérios, castelos). (BARREIRA, 1997, p. 289)

Assim, também na sua produção jornalística e folhetinesca, estão presentes a linguagem da morbidez, o relato de taras e vícios, marcados por um excesso naturalista, fazendo com que esta se aproxime da chamada literatura de terror e horror, e, como tal, seja identificada como "sensacionalista", "subliteratura". É essa parte menos prestigiada da sua produção que nos propomos a examinar nesse breve ensaio.

Tomemos o exemplo das novelas A peste negra, O espelho da marquesa e História de um casamento triste, publicadas em pequenos livrinhos que eram distribuídos de brinde aos assinantes do Diário de Notícias, na coleção que começou em 1866. As três novelas citadas têm como parâmetro genérico a literatura fantástica, pois há no enredo uma situação insólita que suscita ambiguidade, provocando o suspense e gerando a incerteza por parte do leitor, que hesita entre as diferentes possibilidades: alucinação, sonho, manifestação do além. Nos três casos, de uma maneira geral, o eixo gira em torno da personagem feminina, figura satânica que é encarnada na mulher que, bela, sedutora e misteriosa, personifica a mulher fatal, responsável pela desestabilização do herói, e presença quase obrigatória na literatura finissecular. Nos três casos em tela, a mulher fatal reúne em sua figura o hibridismo do Bem e do Mal, de Eros e de 


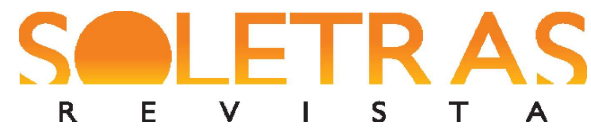

N. $40-2020.2$ - MARIA CRISTINA BATALHA

Thanatos. E, como lembra Cecília Barreira no Prefácio a Peste negra: "A Mulher surge na plenitude da sua beleza ofuscante e transitória. À visão de um corpo belo e inacessível sucedese a morte, ou por assassínio ou por insondáveis trilhos onde nunca se percepciona um motivo ou sequer o porquê de um desfecho fatal" (BARREIRA, 1987, p. 12).

Em A Peste negra (1874), o protagonista, julgando-se atacado pela doença provocada pela peste, foge de sua amante que supõe estar morta. Mas é em vão que tenta esquecê-la, obcecado pela visão da mulher misteriosa, envolta na atmosfera de brancura e pureza das noivas em noites de núpcias, acabando por se deixar possuir pelas forças do mal. Antes de chegar ao leito onde expira a bela mulher, o herói percorre um circuito labiríntico de corredores "húmidos e cheios de eco"(LEAL, 1987, p. 19), através de palácios mal iluminados e soturnos, onde ecoam vozes que não consegue distinguir. Fascinado pela visão dessa formosa mulher moribunda, envolta em véus, cortinas e rendas, em um cenário diáfano de sonho, assiste a cenas de delírio, provocado pela febre característica da doença: "[Os olhos] tinham o brilho estranho dos tísicos irremediáveis, e das pessoas desvairadas da febre” (LEAL, 1987, p. 21). O rapaz, na tentativa desesperada de salvá-la, leva-a nos braços para o seu corcel, mergulhando a galope, num percurso de ímpeto e fantasia, impulsionado pela loucura da viagem e os mistérios da noite. E, de alucinação em alucinação, em várias noites insones e turbulentas, acaba por voltar novamente à alcova da amante estendida em seu leito de morte. Ao final da narrativa, intervém a voz de um velho, que o culpabiliza pela estranha sorte da amada, dizendo que esta teria sucumbido diante do desprezo e abandono provocados por ele.

Percebe-se no relato a exploração de espaços que simbolizam a ambiência satânica, protagonizada pela pouca luminosidade, a decadência, a geografia do labirinto e a evocação dos sentidos que esse cenário desperta: "móveis antigos (...) alguns de preciosas madeiras aromáticas” (LEAL, 1987, p. 20). A linguagem, sempre excessiva, traduz a tensão permanente entre a pureza e a virgindade, marcadas pelos tecidos diáfanos e a predominância da cor branca, e os delírios que o erotismo inspira, levando à alucinação e ao sonho ambíguo: “(...) tudo desliza para a embriaguez apocalíptica, em espiral, num êxtase onde o mistério não se desvenda, antes vai crescendo"(LEAL, 1987, p. 11). No texto, o paradigma da perfeição se conjuga com a eclosão dos sinais subversores: sangue, doença, crime. Após desfrutar de momentos de êxtase no amor, que "extasia e faz perder a razão", o protagonista sente "um pavor inexplicável” e 


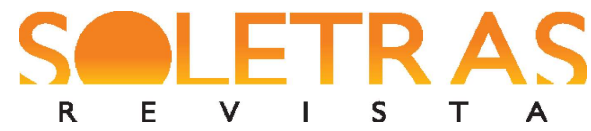

N. $40-2020.2$ - MARIA CRISTINA BATALHA

encontra-se subjugado por uma "prostração mórbida agradável", que suscita misto de terror e exaltação. (LEAL, 1987, p. 23).

Sondando os labirintos do humano, suas zonas opacas e comportamentos desviantes, a literatura finissecular privilegia os diversos espaços de sombra, a morbidez e suas ambiguidades. Parece-nos que a opção pelo fantástico, pela sua própria natureza, é a que melhor se adequava à exploração desses estados d'alma nebulosos. Como lembra Bráulio Tavares:

A tentativa de iluminar com linguagem o inconsciente intocado, ignoto, amorfo, é o impulso que gera na narrativa fantástica toda a clássica topografia dos sótãos, porões, subterrâneos, passagens secretas, portas camufladas, quartos lacrados, labirintos, ruínas ocultas, edifícios abandonados, todas as representações materiais de trechos do real que por uma razão qualquer são escondidos, bloqueados, interditos ou simplesmente abandonados e entregues a si próprios. (TAVARES, 2003, p. 14)

Com efeito, ao final do relato, paira a ambiguidade sobre a real natureza do que o rapaz havia vivido:

Caí sobre o corpo dela desfeito em choro, abalado e indeciso, porque desde tanto tempo que vivo no mundo ideal e da fantasia, como outros no seu quarto e na cela do seu estudo, que às vezes difícil me é distinguir o ideal do real, e tomo por factos e por certezas, teorias e abstracções e sonhos, e tudo é escuro, incerto, e fantástico na minha tenebrosa e excêntrica vida. (LEAL, 1987, p. 42)

A dúvida vivida pelo protagonista traduz a oposição fundamental maniqueísta entre o Bem e o Mal, dialética judaico-cristã, protagonizada pela história simbólica dos irmãos Abel e Caim, e que Baudelaire não fará senão trazer para o interior de cada um de nós. Em Gomes Leal, a concepção dualista do mundo concretiza-se na oposição do Cristo e do anti-Cristo e, por isso, no poema "Na folha de um livro", em Claridades do Sul, o poeta interroga-se: "Em mim vencerá Deus ou ganhará Satan?” (LEAL apud PIRES, 1999, p. 557). A exploração da temática do diabolismo, presença recorrente na literatura frenética, ou literatura de sensação, que, como 


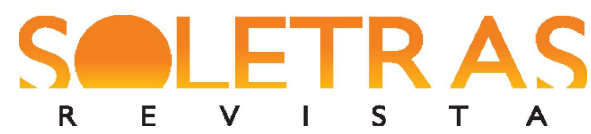

N. 40 - 2020.2 - MARIA CRISTINA BATALHA

vimos, responde ao gosto da época, ilustra de modo inequívoco a dicotomia na qual o homem do século XIX se debatia e que levava a um certo esgotamento nervoso.

Como assinala Daniel Augusto P. da Silva, um dos motivos de preocupação dos escritores do fim do século, e que justificava o fracasso dos tempos, era a neurastenia, ou seja, o enfraquecimento dos nervos e a consequente fraqueza do comportamento. Porém, como lembra o crítico, isso também poderia significar o refinamento da sensibilidade e da capacidade de fruição estética. Este fator instaura nos jovens artistas europeus um sentimento de instabilidade nervosa, contribuindo significativamente para o desenvolvimento de uma imprensa e de uma ficção de cunho mais sensacionalista, explorando a predisposição do público para vivenciar emoções cada vez mais fortes (SILVA, 2019, p. 10).

De fato, destaca-se nessa novela a presença predominante de personagens obsessivos e paranoicos que tendem ao macabro e ao horror, e que são a expressão do sentimento de decadência e pessimismo generalizados que marcam a literatura do período, expressão de uma concepção desencantada da existência diante de uma sociedade que se moderniza e também se desestabiliza. Esse quadro de referência traduz-se na figura predominante da "mulher fatal", concepção maléfica da mulher como símbolo de morte e de sublime, cuja descrição física e psicológica têm algo de satânico, mas que também sugere um certo masoquismo que, ligado ao seu contraponto, o sadismo, exprime a visão dualista do homem. Assim, o misto de figura satânica e a presença da noiva pura em noite de núpcias é personificada na mulher, expressa pela escolha dos oxímoros que a definem: "fatalmente bela e irreparavelmente sedutora" (LEAL, 1987, p. 23). É então a figura feminina que engendra a eclosão do hibridismo presente no relato: Mal, Eros, Morte. Quando Eros é confrontado com a dor e a morte, provoca uma tensão erótica, reduplicada pela sugestão do vampirismo aludido no texto, levando ao delírio e ao mistério. Como lembra Cecília Barreira em seu Prefácio, “(...) no estranho fascínio do universo em que mergulham os contos de Gomes Leal a beleza é sempre sinónimo de opacidades indecifráveis" (BARREIRA, 1987, p. 12). Por isso, diz ela, "Esta estranha conjugação de forças coloca o feminino por um lado na situação de vítima, por outro, na de carrasco de um destino também ele inexpugnável e eletrizante” (BARREIRA, 1987, p. 10). A plenitude amorosa torna-se então incompatível com a felicidade, e as metáforas de pureza e podridão que percorrem toda a narrativa expressam exaustivamente essa disjunção: "Todas as mulheres que depois amei me morreram nos braços; frias, pálidas, murchas, na noite do 


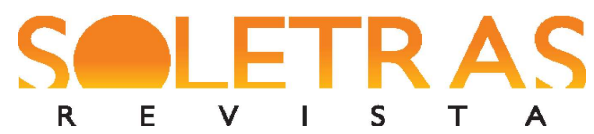

noivado, e desfolhada a coroa de laranjeira (...) meu leito nupcial transformou-se de cada vez num sepulcro" (LEAL, 1987, p. 36-37). Como vimos, a representação do feminino esconde-se na morte e no apocalipse; daí o seu caráter paradigmático na produção ficcional de fim de século.

A presença ambígua da mulher fatal também é o motivo central da novela $O$ espelho da marquesa (1880), no qual três atitudes diante do amor se superpõem: a paixão devastadora, a devassidão dos aristocratas e a frieza inquietante, vividas por seres excessivos, movidos por fortes impulsos. Também aqui a representação da mulher é prioridade fundamental na composição de sua poética: ambiente de castidade e volúpia, melancolia e sedução, e nesta ambivalência contrastam-se as imagens que remetem à frieza do mármore e ao calor vibrante de um sentimento subterrâneo: "e nunca durante dois anos que a tratava, lhe surpreendi um estremecimento que denunciasse um remorso, uma nuvem que empanasse aquela serenidade dum belo mármore, e que revelasse o crime!” (LEAL, 1987, p. 61).

Se observarmos os dois primeiros parágrafos que abrem a novela, vemos expostas, à guisa de um manifesto, as linhas de força que orientam a poética do autor, em estreita consonância com o seu tempo:

Uma enfermidade moral que deu cabo um dia do meu sossego e da minha felicidade para todo o sempre! foi esse dom diabólico, que eu possuo, da observação.

Este contágio, que se apossou de repente de todo o século, de analisar a microscópio todo o mundo físico e as sensações mais inatingíveis da alma, esta epidemia fria de realismo e de enterrar, sentindo as mais cruciantes dores, o bisturi do nosso próprio coração, e até da mulher que amamos, esta agonia nevrálgica da análise, matou-me um dia o coração, e entenebreceu-me de todos os lutos trágicos das desolações eternas a existência. (LEAL, 1987, p. 45)

$\mathrm{Na}$ obra em tela, o protagonista, movimentando-se em salões da alta sociedade, encontra uma mulher casada, cuja visão o perturba particularmente. Na noite em que esta lhe é apresentada, valsa com ela num rodopio de sons, aromas e movimentos por salões intermináveis. Apaixonado, afoita-se em descobrir mais pormenores sobre a vida íntima da sedutora e enigmática marquesa. Alguém lhe confia um segredo/suspeita: a marquesa 


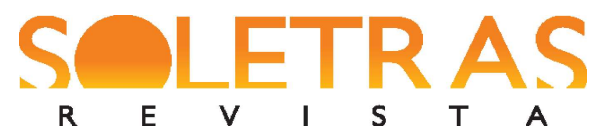

N. $40-2020.2$ - MARIA CRISTINA BATALHA

envenenara lentamente a própria irmã até a morte para poder casar-se com o cunhado pelo qual tinha se apaixonado. O rapaz resolve então descobrir a verdade a respeito desta suspeita, tornando-se amigo íntimo do casal. Após algum tempo, conjugando perversidade e paixão, num tortuoso diálogo com a marquesa e por estratagemas ardilosos, essa suspeita é então confirmada. Movido por um propósito obsessivo que oscila entre o querer e o não querer saber, engendra uma cena em que a marquesa vê-se confrontada duplamente com a sua culpa: através da peça de teatro à qual assistem, Macbeth, e da imagem de sua própria culpa refletida no espelho, outra forma de simulacro que é então reduplicada. Não resistindo afinal ao jogo perverso arquitetado pelo amigo, acaba atingida fatalmente pelo peso dessa culpa. E o herói romântico chora perdidamente a vítima da sua própria perversidade.

Mas então um grito agudo, um grito que resumia todas as notas mais diversas da dor humana - o remorso, a agonia, a surpresa, a alucinação, mas sobretudo o medo, o intensíssimo medo, veio ferir o meu ouvido, com todo o cortejo de notas extraordinárias que jamais feriu tímpano algum humano. Era a marquesa que soltava, cair fulminada no tapete. (LEAL, 1987, p. 81)

Em meio ao enredo de ciúmes, paixão e morte, o protagonista, dandy sofisticado, obsessivo e voluntarioso, circula por cenários de luxo, refinamento e excentricidades, buscando vencer o tédio de sua própria existência, à espreita de sensações novas e excitantes, sem, contudo, abrir mão, como veremos no enxerto abaixo, da ironia que revela a atitude blasé:

A imaginação mais positiva sofre levada pelo braço de uma escultura, de uma bela flor de carne alimentada nas estufas da opulência, a morbideza e a influência do meio em que valsa, das sinfonias a que se balança, numa inconsciência e abstracção deliciosa da realidade, e às vezes dos calos terciários. (LEAL, 1987, p. 50)

Cabe lembrar que o poder de sedução do dandismo é constante, porém sempre ambíguo, já que, capaz de inspirar paixões arrebatadoras, também revela-se ilegítimo e fatal. A tensão erótica presente aqui, no triângulo amoroso, resulta da inadequação entre uma 


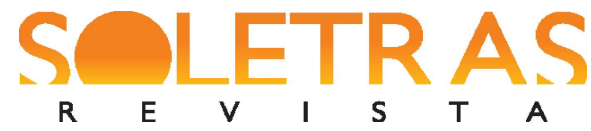

N. $40-2020.2$ - MARIA CRISTINA BATALHA

determinada atmosfera de erotismo e sedução e a iminência da confissão do crime cometido, deflagrando o desfecho fatal que provocará a morte dos amantes: uma real, a outra, na forma do remorso: “(...) com um grande grito de ameaça, de indignação, e de justiça superior, o meu coração gritou-me: Ah! de que te serviu a tua crueldade! Agora eu morrerei, mas tu sobreviverás com teu remorso, aniquilado para todo o sempre!... MALVADO!’(LEAL, 1987, p. 81).

Como lembra Cecília Barreira, trata-se do "reencontro da culpa com a paixão. A culpa é o lugar da consciência ferida, enquanto o desejo, esse, assinala a ferocidade dos instintos, o nível do inconsciente e do que não é reprimível” (BARREIRA, 1987, p. 12). Assim, bem ao gosto da época, o autor perscruta as nuances da sexualidade em suas mais recônditas manifestações e excentricidades, vividas sob o peso da dicotomia da elevação e da queda, origem da culpa cristã e raiz do remorso. Esse viés diretor sustenta a presença de uma retórica que estimula um pathos de exaltação, buscando levar o leitor ao êxtase através de emoções extremadas, muitas vezes provocadas pelo horror e de gosto duvidoso:

E agora estava ali diante de mim, envolta nas suas peliças, calada e friorenta, varada pelo olhar da minha observação, julgada como uma ré pela minha consciência. Tinha-a ali! Mas eu continuava a querê-la! O meu olhar sôfrego corria como uma ânsia histérica, ou de pantera de Java engaiolada, das pontas dos seus cabelos à ponta esboçada da sua botina de cetim, e da moda. (LEAL, 1987, p. 77 )

A exploração do universo interior leva a capacidade imaginativa do escritor a esferas insondáveis do comportamento humano e à presença de uma uma sexualidade marcada pela ambiguidade, reduplicada pelo potencial imaginativo suscitado pela "mulher fatal", misto de prazer e dor. A sondagem das zonas subterrâneas do desejo erótico fica bastante evidente na novela História de um casamento triste (1880), que traz precisamente como subtítulo (Estudo de mulher) .

Trata-se de uma narrativa emoldurada, na qual o protagonista relata a um grupo de amigos a história de seu casamento que nunca chegou a se concretizar efetivamente, pois, sua mulher, “dada às contemplações divinas, e de um misticismo melancólico”(LEAL, 1987, p. 9), recusava-se a consumar sexualmente o ato. Diante dessa recusa sistemática, o amor do marido pela esposa crescia cada vez mais, e seu desespero aumentava, vislumbrando algum mistério 


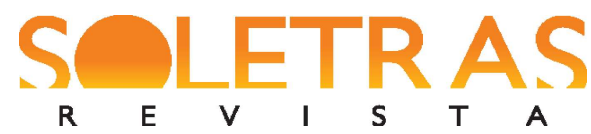

N. $40-2020.2$ - MARIA CRISTINA BATALHA

escondido por trás dessa recusa. "Mais tarde percebi, depois de muitas tristes noites como esta de noivado, que havia desposado uma estátua" ( LEAL, 1987, p. 13). Ademais, corria a lenda dos lobisomens que rondavam a região e isso incomodava sobremaneira o pai da moça, descrente da tão difundida lenda popular, mas sobre quem recaía a suspeita de transformar-se em lobisomem, dado seu comportamento misterioso e arredio, além da suspeita de uma estranha movimentação de vultos deambulando pelos jardins da casa durante algumas noites. Evocando o mistério que envolvia a residência, Gomes Leal faz uso da "estética do mistério", como a nomeia Cecília Barreira (1985, p. 261), servindo-se de uma retórica dos subterrâneos e da morbidez: "Logo nos primeiros tempos que fora para aquela casa, as paredes com que me tinham parecido inóspitas; e os móveis, os retratos, as salas com aquele ar de abandono e de frieza, que é, como uma sepultura" (LEAL, 1987, p. 23). A frieza do lugar contrasta com o "abismo humano sem fundo, que se chama paixão", experimentada pelo rapaz, que mergulha "num desesperado desalento (...), pelo encanto misterioso da minha esposa" (LEAL, 1987, p. 25), evidenciando a duplicidade do jogo amoroso de prazer e dor, calor da paixão e frieza da mulher, com uma carga de erotismo notória e crescente: "sentia-me naquela terrível crise nervosa, em que um homem comete um crime ou uma cobardia” (LEAL, 1987, p. 25).

Após várias tentativas infrutíferas para conquistar a esposa, o marido resolve fingir-se de outra pessoa, simulando um misterioso sedutor a rondar os jardins da residência da família, a enviar bilhetes amorosos à bela senhora, como estratégia para conquistar a mulher e movido pelo "desejo de vingar o [s]eu amor próprio ofendido, e não o de possuir completamente [sua] esposa, só pelo amor da posse" (LEAL, 1987, p. 28). Ao passo que, em casa, a mulher "não aumentara nem diminuíra na sua frieza" (LEAL, 1987, p. 35), esta responde aos seus bilhetes amorosos com "grande platonismo" e uma "pura poesia espiritualista" (LEAL, 1987, p. 34).

Após um longo período de jogo amoroso entre o misterioso apaixonado e a bela e casta senhora, os dois apaixonados marcam um encontro noturno, nos jardins da casa. Nesse momento, é então revelada a identidade do amante, despertando, finalmente na esposa "bachante" e "pura" (LEAL, 1987, p. 39) o amor tão esperado. Entretanto, invertem-se os papéis: “- Eu odeio-te, dizia-lhe com desprezo. Fazes-me tédio. Não te posso ver. Amanhã saio desta casa... (...) És uma mulher depravada pelos romances. A tua castidade é falsa, falsa como esta sociedade... falsa como a infâmia dourada... falsa como Judas...” (LEAL, 1987, p. 40). 


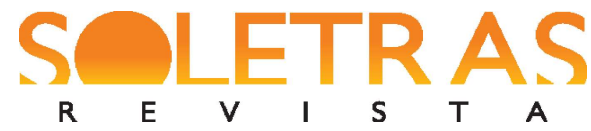

Antes insensível aos apelos apaixonados do marido, agora a mulher tenta de todas as maneiras conquistar o amor do marido e consumar o casamento, vestindo-se de noiva, como se fora a noite de núpcias:

(...) minha mulher estava tão bela, tão pudicamente encostada ao leito, com seu fato de noiva, e o seu comprido vestido branco, que foi realmente com um esforço sobre mim mesmo que me cheguei a ela, e, pegando-lhe num braço, lhe disse: - É preciso que nos deitemos; adeus. E empurrei-a para a porta."(. 42) Reprimindo seu desejo erótico, só volta ao quarto nupcial no dia seguinte, constatando, contudo, que "[sua] mulher com o seu fato de noiva, os seus cabelos caídos, os olhos fechados, duma palidez diáfana e láctea, estava caída contra a porta, no chão. (...) Estava morta. (LEAL, 1987, p. 44)

Unem-se Eros e Thanatos para nos lembrar que o amor é indissociável da morte: Eros, ao invés de permitir uma fusão ideal, que seria a "confirmação da identidade por intermédio de um espelho euforizante", tem um efeito destruidor (AURAIX-JONCHÈRE, 1999, p. 135). Assim, o leito nupcial torna-se o lugar da expiação e do suplício da mulher amada, fazendo vir à tona o universo subterrâneo de um desejo erótico inapreensível e oculto, introduzindo a desordem e o caos. Como bem observa Cecília Barreira: “(...) a mão assassina é insondável nos seus desígnios: não há uma explicação racional e plausível, porque tudo se passa na zona subterrânea dos instintos, dos desejos, das pulsões" (1997, p. 292). Assim, diz a crítica, “o desejo é possante e violento e para atingir um absoluto tem de passar pela execução do objeto que elegeu. A violação é transferida, assim, para a morte: a morte consagra o prazer último através do elemento sangue" (BARREIRA, 1997, p. 294).

$\mathrm{O}$ conto se fecha com um mistério, deixando margem a várias possibilidades de interpretação. Apesar de os médicos não conseguirem diagnosticar a doença que a levara, o pai da moça, ao cruzar com o agora viúvo, diz-lhe ao ouvido que, o tempo todo, ele "sabia de tudo" (LEAL, 1987, p. 45), confirmando, talvez, a crença popular do lobisomem atribuída ao Sr. Lançada, pai da jovem, "homem misterioso, sábio e paranóico". Sugere-se que este, por desejar incestuosamente a filha, incutira-lhe um respeito excessivo, a culpa e o medo, impedindo a relação carnal entre os esposos. 


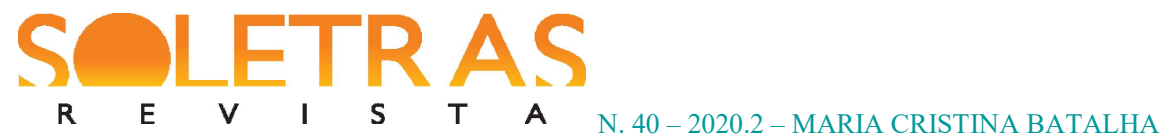

Em Prefácio à obra $A$ peste negra, reeditada na coleção Fantástico, pela Editora Rolim, Cecília Barreira pergunta-se:

Em que universos concêntricos se move afinal o imaginário do poeta do satanismo, talvez a única voz autenticamente hoffmaniana do nosso romantismo? Primeiro, o da ambivalência Eros/Morte, onde o paradigma da Perfeição se conjuga na eclosão dos sinais subversores, sangue, doença, crime. Segundo, o da desequilibrante estrutura de labirintos. São os corredores sem fim e algo alucinantes de palácios, são caminhos, vertigens, viagens a galope para nenhures. Terceiro, o reencontro da Culpa com a Paixão. A culpa é o lugar da consciência ferida, enquanto o desejo, esse, assinala a ferocidade dos instintos, o nível do inconsciente e do que não é reprimível. (BARREIRA, 1987, p. 12)

Com efeito, se a historiografia literária reserva um lugar secundário ao contista Gomes Leal, não podemos esquecer que ele ocupou um espaço significativo na cena literária do final do século XIX, tendo colaborado para diversos jornais e revistas da época.

A exibição do "escândalo do mal", a hipertrofia de metáforas do grotesco e de cenas sangrentas, as representações do horror e de um erotismo macabro constituem os elementos frenéticos que permeiam a cenografia enunciativa (MAINGUENEAU, 2006) das principais obras a partir da metade do século XIX e estes são os elementos responsáveis por abalar os limites do verossímil, infringindo as regras acadêmicas e o chamado "bom-gosto". Como declara Andreia Monteiro de Castro:

As narrativas, produzidas em uma linguagem simples e hiperbólica, eram publicadas com grandes e sequenciais ilustrações, permitindo uma rápida apreensão do assunto abordado. O sangue fez vender muita tinta e papel. Tornadas um pouco mais discretas na vida quotidiana burguesa, a brutalidade funesta e a licenciosidade apaixonavam o povo. (CASTRO, 2017, p. 44)

E a popularidade do fait divers repousa no impacto, na surpresa e no suspense produzidos, mas também no prazer provocado pelo espetáculo do sangue, pelas explosões de 


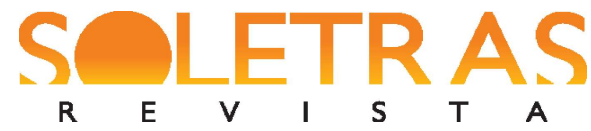

N. $40-2020.2$ - MARIA CRISTINA BATALHA

desejos, sonhos e fantasias recalcados, servindo de válvula de escape para a burguesia reprimida que vivia, através da emoção, um momento de fuga e descompressão (CASTRO, 2017, p. 44).

Como vimos, a corrente estética chamada depreciativamente de "literatura frenética", filial exacerbada e subversiva do romantismo francês, carrega os traços do romance gótico, do erotismo escatológico de Sade e do grotesco - que perdem seus fundamentos religiosos e moralizantes- , traduzindo-se em uma forma de mau-gosto voluntário e assumido, na qual impera o macabro, o horror e a hipertrofia das metáforas escabrosas, expressão de um pathos exaltado. Como uma versão moderna do inferno de Dante, a estética gótica explora os locais da distopia e da amoralidade, exibindo personagens movidos por forças destrutivas, em seus estados fóbicos, melancólicos e desequilibrados. Neste último caso, a opção pelo gótico seria uma reação contra a ditadura do bom-gosto, tornando-se a expressão privilegiada para a composição da estética do frenesi. Isso explica o sucesso obtido pelos Mistérios de Paris, de Eugène Sue, romance-folhetim traduzido imediatamente em várias línguas e disseminando-se por vários países, em produtivo processo de emulação, promovendo um elo entre o gótico e o Naturalismo, e alimentando os quadros de horror e os melodramas que se mantêm por longo tempo em Portugal. Assim, na literatura finissecular, a beleza se redefine em sua relação estreita com a violência e o crime. Por outro lado, o satanismo praticado por Gomes Leal, surge como uma forma de liberdade, "de gosto pelo excesso, hipótese de fuga ao quotidiano" (PIRES, 1999, p. 558), já que o escritor finissecular tenderá a fugir do presente hostil e pouco edificante, “inventando (...) um mundo soturno bárbaro e desesperado" (FERREIRA, s/d, p. 90) .

Em "Carta ao Dr. Campos Salles", que abre o volume de Fim de um mundo, Gomes Leal, em seu desabafo, traça um retrato desencantado do final do século:

Termina o século no meio de um apocalipse social; no meio de farrapos de declamações; farrapos luzentes de teorias; farrapos trágicos de esfomeados... Como, nos finais do melodrama romano, os retóricos declamam, enquanto os belfurinheiros batem à porta, e a gentalha se esbofeteia. Quebram-se os vidros dos palácios, e aplaudem-se os polemistas (...). Que importam porém as vidraças dos palácios, flamejantes das lâmpadas elétricas (...)? É a alguma coisa de mais alto, mais inviolável, mais espiritual, que se atiram pedras. O direito, a moral, as religiões, as instituições, os costumes, as consciências, como pardieiros velhos e escavados, por onde passou a labareda de um incêndio, ou o solavanco de um cataclismo, mostram, por toda parte, os 
buracos... (...) a civilização hodierna cristã representa a túnica de Cristo em frangalhos." (LEAL, 1899, pp. VII-VIII)

E, em conclusão nada lisonjeira sobre o legado de Gomes Leal, na conferência proferida no Palácio Galveias por ocasião da inauguração da Exposição comemorativa do centenário de nascimento do autor, sentencia Mário de Sampayo Ribeiro:

Ao passo que os românticos eram idealistas da mais pura cepa, os seus adversários blasonam de realismo e de positivismo, de modo que o mundo deixa de ser visto de prismas cor-de-rosa, mas passa a ser-nos mostrado pelo revés - negro, a escorrer podridão, qual esterquilínio nauseabundo. A maldade vem para o primeiro plano e é estudada com amor de maneira que chega a parecer-nos bela e a ser, se não enaltecida, ao menos justificável e desculpada. De todos e de cada um dos factores enumerados - e de outros somenos que, por abreviar, calei - resultou, e está resultando ainda, muita coisa, quer no campo artístico, quer no das letras. (...) Todos os factores enumerados actuaram sobre Gomes Leal e de todos eles foi mais ou menos vítima. (RIBEIRO, 1949, pp. 14, 15, 17)

\section{Referências}

AURAIX-JONCHÈRE, Pascale. Les Diaboliques, de Barbey d'Aurevilly. Notes et Présentation. Paris: Gallimard, 1999.

BARREIRA, Cecília. "A representação do feminino na obra de Gomes Leal", in O conceito de representação. Revista da Faculdade de Ciências Sociais e Humanas, Universidade Nova de Lisboa, n. 10, Lisboa: Edições Colibri, 1997, pp. 287-295.

. Prefácio a A peste negra, de Gomes Leal. Lisboa: Rolim, 1987, col. Fantástico, n. 33.

BRUNO, Sampaio. A geração nova. Porto: Chardron/Lello \& Irmãos, 1984.

CASTRO, Andrea Alves Monteiro de. "Realidades, desejos, crimes e ficções: as cidades de Camilo Castelo Branco e Gervásio Lobato". Tese de Doutoramento em Literatura Comparada, Universidade do Estado do Rio de Janeiro, Rio de Janeiro, 2017.

FERREIRA, Alberto. Perspectiva do romantismo português. Lisboa: Litexa, 3. Ed., s/d. 


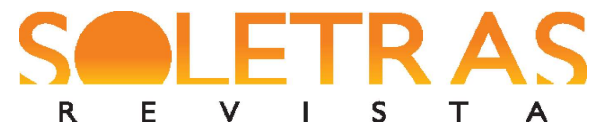

N. $40-2020.2$ - MARIA CRISTINA BATALHA

FRANCISCO, Elisabete Correia Campos. "Entre a ficção e a realidade: um olhar histórico sobre as personagens queirozianas". In: LOURENCO, António Apolinário, SANTANA, Maria Helena \& SIMÕES, Maria João (Orgs.). O Século do romance-Realismo e Naturalismo na ficção oitocentista. Centro de Literatura Portuguesa, Faculdade de Letras da Universidade de Coimbra, 2013, pp. 129-139.

LEAL, António Gomes. A Peste Negra. Diário de Notícias, $1874,9^{\circ}$ Brinde aos assignantes. Catálogo da Biblioteca Pública Municipal do Porto:

$<$ https://books.google.com.br/books?id=JppPAQAAMAAJ\&lpg=PA28\&ots=_nX_wauvlo\&d $\mathrm{q}=\% 22 \mathrm{Hist} \% \mathrm{C} 3 \% \mathrm{~B} 3 \mathrm{ria} \% 20 \mathrm{de} \% 20 \mathrm{um} \% 20$ casamento $\% 20$ triste $\% 22 \% 20$ gomes $\% 20$ leal $\& \mathrm{hl}=\mathrm{p}$ $\mathrm{t}-\mathrm{PT} \& \mathrm{pg}=\mathrm{PA} 28 \mathrm{Av}=$ onepage $\& \mathrm{q} \& \mathrm{f}=$ false $>$. Acesso em: 12 de abr. 2020.

. O Espelho da marquesa. Diário de notícias, $16^{\circ}$ Brinde aos assignantes, 1880.

Catálogo da Biblioteca Pública Municipal do Porto:

$<$ https://books.google.com.br/books?id=JppPAQAAMAAJ\&lpg=PA28\&ots=_nX_wauvlo\&d $\mathrm{q}=\% 22 \mathrm{Hist} \% \mathrm{C} 3 \% \mathrm{~B} 3 \mathrm{ria} \% 20 \mathrm{de} \% 20 \mathrm{um} \% 20$ casamento $\% 20$ triste $\% 22 \% 20$ gomes $\% 201$ eal $\& \mathrm{hl}=\mathrm{p}$ t-PT\&pg=PA28\#v=onepage\&q\&f=false $>$. Acesso em: 12 de abr. 2020.

História de um casamento triste. Diário de notícias, $11^{\circ}$ Brinde aos assignantes, 1880. Catálogo da Biblioteca Pública Municipal do Porto:

$<$ https://books.google.com.br/books?id=JppPAQAAMAAJ\&lpg=PA28\&ots=_nX_wauvlo\&d $\mathrm{q}=\% 22 \mathrm{Hist} \% \mathrm{C} 3 \% \mathrm{~B} 3 \mathrm{ria} \% 20 \mathrm{de} \% 20 \mathrm{um} \% 20$ casamento $\% 20$ triste $\% 22 \% 20$ gomes $\% 20$ leal $\& \mathrm{hl}=\mathrm{p}$ t-PT\&pg $=$ PA28\#v=onepage \&q\&f=false $>$. Acesso em: 12 de abr. 2020.

. Fim de um mundo. Porto: Chardron, 1899.

A peste negra, seguida de $O$ espelho da marquesa. Lisboa: Rolim, 1987, col. Fantástico, n. 33.

História de um casamento triste. Lisboa: Rolim, 1987, col. Fantástico, n. 19.

MACHADO, Álvaro Manuel. Les romantismes au Portugal, modèles étrangers et orientations nationales. Paris: Fondation Calouste Gulbenkian, 1986.

. "Gomes Leal, Baudelaire e o Pós-Romantismo finissecular". In Intercâmbio, n. 3, Porto: Instituto de Estudos Franceses da Universidade do porto, 1992, pp. 108-130.

MAINGUENEAU, Dominique. O contexto da obra literária. 2a ed. Trad. Marina Appenzeller. São Paulo: Martins Fontes, 2001.

MARCANDIER-COLARD, Christine. Crimes de sang et scènes capitales. Essai sur l'esthétique romantique de la violence. Paris: PUF, 1998.

MELLO, Celina Maria Moreira de. Crítica literária, política e revolução estética em L'Artiste (1831-18320). In MELLO, Celina Maria Moreira de. \& CATHARINA, Pedro Paulo Garcia 


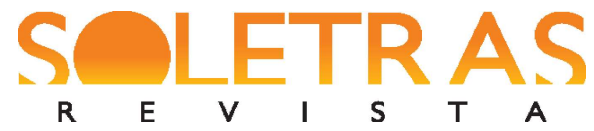

N. $40-2020.2$ - MARIA CRISTINA BATALHA

(Orgs.). Crítica e movimentos estéticos, configurações discursivas do campo literário. Rio de Janeiro: 7 Letras, 2006, pp. 13-61.

NEMÉSIO, Vitorino. Destino de Gomes Leal. Seguido de Poesias escolhidas. Lisboa: Bertrand, 1953.

PIRES, Maria da Natividade. "Eugénio de Castro e António Duarte Gomes Leal. Um diálogo de visionários". In Arquivos do Centro Cultural Calouste Gulbenkian, vol. XXXVIII, Lisboa, Paris, 1999.

RIBEIRO, Mário de Sampayo. O Drama de Gomes Leal. Lisboa: Publicações Culturais da Câmara Municipal de Lisboa, 1949.

SILVA, Daniel Augusto Pereira. A prosa de ficção decadente brasileira e francesa (18841924): uma poética negativa. Dissertação de Mestrado. Instituto de Letras, Universidade do Estado do Rio de Janeiro, Rio de Janeiro, 2019.

TAVARES, Braulio. Páginas de sombra: contos fantásticos brasileiros. Apresentação. Rio de Janeiro: Casa da Palavra, 2003.

\title{
The fin-de-siècle frenetic literature in Gomes Leal's feuilletons
}

\begin{abstract}
António Duarte Gomes Leal (1848-1921), one of the youngest writers of the 1870's generation, produced several novellas characterized by an erotic tension, inscribed between delirium and mystery, in the form of the so-called "frenetic literature", dominant, in France, in the earlier nineteenth century, and the late nineteenth century Portugal, during the "Decadentism" period. In his work, Eros is submitted to pain and death, and the violent passions occur in dark and macabre spaces, where there's a strong feeling of imprisonment before outdoor spaces (cemeteries and castles). The satanism manifests itself in the taste for excess and frenzy. From three of Gomes Leal's novellas, published in fascicles as gifts to the readers of Diário de Notícias, we analyze the creation of a fictional universe of fantastic and grotesque, masochism and sadism, which also expresses a dualistic vision of the humankind, inspired by Baudelaire and appealing to the public of the late nineteenth century feuilletons.
\end{abstract}

Keywords: Gomes Leal. Frenetic Literature. Feuilleton. Decadentism.

Recebido em: 13 de maio de 2020.

Aceito em: 16 de junho de 2020. 